\title{
To be a Feminist in (Tourism) Academia
}

\author{
Munar, Ana Maria
}

Document Version

Accepted author manuscript

Published in:

Anatolia: An International Journal of Tourism \& Hospitality Research

DOI:

10.1080/13032917.2017.1370777

Publication date:

2017

License

Unspecified

Citation for published version (APA):

Munar, A. M. (2017). To be a Feminist in (Tourism) Academia. Anatolia: An International Journal of Tourism \& Hospitality Research, 28(4), 514-529. https://doi.org/10.1080/13032917.2017.1370777

Link to publication in CBS Research Portal

\section{General rights}

Copyright and moral rights for the publications made accessible in the public portal are retained by the authors and/or other copyright owners and it is a condition of accessing publications that users recognise and abide by the legal requirements associated with these rights.

Take down policy

If you believe that this document breaches copyright please contact us (research.lib@cbs.dk) providing details, and we will remove access to the work immediately and investigate your claim. 


\section{To be a Feminist in (Tourism) Academia}

\section{Ana Maria Munar}

Journal article (Accepted manuscript*)

\section{Please cite this article as:}

Munar, A. M. (2017). To be a Feminist in (Tourism) Academia. Anatolia: An International Journal of Tourism \& Hospitality Research, 28(4), 514-529. D0l: 10.1080/13032917.2017.1370777

This is an Accepted Manuscript of an article published by Taylor \& Francis in Anatolia: An International Journal of Tourism \& Hospitality Research on 04 Sep 2017, available online:

DOI: http://www.tandfonline.com/10.1080/13032917.2017.1370777

* This version of the article has been accepted for publication and undergone full peer review but has not been through the copyediting, typesetting, pagination and proofreading process, which may lead to differences between this version and the publisher's final version AKA Version of Record.

Uploaded to CBS Research Portal: March २०19 
Accepted version of research article published as: Munar, A. M. (2017). To be a feminist in (tourism) academia. Anatolia. DOI: 10.1080/13032917.2017.1370777

To link to this article's published version: http://dx.doi.org/10.1080/13032917.2017.1370777

This article is part of the special issue "Gender and the Tourism Academy" edited by Ana María Munar, Donna Chambers, Catheryn Khoo-Lattimore and Avital Biran and published in "Anatolia".

\title{
To Be a Feminist in (Tourism) Academia
}

\author{
Ana María Munar ${ }^{1}$ \\ Copenhagen Business School, Denmark
}

\begin{abstract}
This study explores what it means to be a feminist in (tourism) academia. Different understandings of feminist identity and their ethical and political dimensions are examined using the method of the vignette. This technique is applied as an autoethnographic and narrative tool that facilitates the exploration of feminism from multiple viewpoints. Three characters, SherylAna, Gloria-Ana, and Gaga-Ana, are presented, drawing inspiration from the literature and my own life experiences, research and activism in tourism academia. These narratives are followed by a discussion on multiple ways of doing academic feminism and demonstrating our capacities for political engagement.
\end{abstract}

Keywords: feminism; higher education; gender; activism

\section{Introduction}

Who was I? Today's self, bewildered, yesterday's forgotten; tomorrow's unpredictable? (Borges - in Postmodernism from Harvey p. 41)

"Ana, you are so vocal on the issue of gender equality that everybody will see you as a "feminist"'. A few years ago, a highly respected academic made this remark with a sense of admiration and as a friendly warning. "He is probably right" I thought, while visualizing a sudden drop on an imagined likeability scoreboard. However, the possibility of being less liked was not why I kept coming back to this conversation for a long time after that episode. It was because of my inability to understand how people imagine what a feminist tourism academic is. It seemed impossible to reach an understanding that went beyond stereotypes. I kept wondering: What is it that one "sees" when one labels someone a feminist? What does a feminist identity mean in tourism academia today? What are the consequences of such an identity? And to ask an

\footnotetext{
${ }^{1}$ Ana María Munar, Department of International Economics and Management, Copenhagen Business School, Porcelænshaven 24B, 2000 Frederiksberg, Denmark. E-mail: amm.int@cbs.dk
} 
existentially distressing question, if I am defined as a feminist academic, then what am I? And what about you, dear reader, what does "a feminist" mean to you?

This anecdote prompted the need to analyse the meaning of the word "feminist" in an academic context, and what follows is the result of this intellectual exploration. In this study, I make sense of this concept through a mix of scholarly publications, the popular media and my own personal experiences. The methodological approach follows Foucault's invitation to "develop action, thought and desires by proliferation, juxtaposition, and disjunction" and "to prefer what is positive and multiple, difference over uniformity, flows over unities, mobile arrangements over systems" (Foucault, as cited in Harvey, 1989, p. 44). This approach is also inspired by a feminist epistemological tradition, which reintegrates values and emotions into our research activities (Narayan, 1997, p. 214) and suggests that "ethical and political values cannot be eliminated from good epistemic practices, but rather play a legitimate epistemic role" (Grasswick, 2011, p. xviii). As my existential unease indicates, this study is not only a scholarly exercise, but an answer to an ethical need. I wanted to understand how to act and live better, so I embarked on a journey of reading how people defined "a feminist" and the logic behind feminist theories, alongside taking part in academic debates, designing policies for a more equitable workplace and writing research reports on gender equality in academia. My engagement and activism took place in international tourism research networks and other academic settings unrelated to tourism at my university.

What I am sharing with you here is both an epistemic journey (an exploration of knowledge) and an ethical journey (a discussion of morality, or "the right thing to do"). Authors such as Habermas (1989) and Foucault (2000) remind us that meaning(s) and our understanding of concepts help shape the world and ourselves, including our academic worlds and identities. Beyond this, they show us that our experiences, the ways in which we make sense of the world and the things we identify ourselves with define our political capacities (how we want to act, and how we do act). The power of a concept's meaning(s) seems to be especially poignant when it has a strong ordering element attached to it (e.g. terms defining sexual, ideological or political identities), and when meanings do not only provide the possibility for others to control the behaviour of individuals by labelling them, but individuals internalize specific understandings and monitor themselves in an effort to conform to these (Foucault, 1995). To understand the concepts that define us has consequences for the opportunities, joys and sufferings of people (and ourselves) and therefore there is an intrinsic moral dimension to be acknowledged that cannot be separated from working in the production of knowledge (Caton, 2012; 2016).

\section{Who is a feminist?}

The notion of giving something a name is the vastest generative idea that was ever conceived (Susanne Langer, cited in Gloria Steinem's autobiography My life on the Road 2015, p.108).

The word "feminist" has a full palette of colours attached to it, which can lead to a variety of judgments and prejudices. It is a concept soaked in history and in imaginaries of bodies, personal stories, emotions and specific social contexts. A feminist is "a person who supports feminism" (The Oxford Dictionary, 2016), one "who believes in the social, political and economic equality of the sexes" (Adichie, 2014, p. 47) or in the "the radical notion that women are human beings", according to Cheris Kramarae, the author of the Feminist Dictionary (Kramarae, Treichler, \& 
Russo, 1992). These definitions are the less polemic understandings of the word. Few scholars will deny that women are human. If this was all that being "a feminist" meant, we could conclude this enquiry here by agreeing that in the tourism academy we are all feminists, and I would keep wondering why my colleague made the concerned remark with which I began my introduction. However, the reality is more complex than this. "Feminism, regardless of its moment in time, is fundamentally about transforming patriarchal culture and society" (SnyderHall, 2010, p. 265, cited in Parry \& Fullagar, 2013) or as Sebestyen puts it, "building a movement aimed at overthrowing patriarchy [...] is the essence of feminism" (2016, p. 3). Swain refers to Hooks' (2000) classic definition of feminism as "a social/cultural 'movement to end sexism' or inequality based on gender and sexuality" (2016, p. 89) and sexism here means the act of "prejudice, stereotyping, or discrimination, typically against women, on the basis of sex" (Oxford dictionary, 2016). These definitions see feminism as a reaction to a situation of inequality or injustice (i.e. the disadvantage or oppression of women) and link to the many existing prejudices and stereotypes surrounding this concept.

\section{Feminist identity and prejudice}

Studies of unconscious and implicit bias (the non-reflective way by which we tend to evaluate people) and prejudice explain how stereotypes can be captured by the dimensions of warmth and competence (Fiske, Cuddy, Glick, \& Xu, 2002). Individuals are psychologically programmed to be liked and want to score highly on the "warmth" dimension of the scale. While career-oriented men can fit comfortably on both sides of the scale (and be seen as responsible partners/parents and highly competent professionals), the situation can be different for women.

Men and women are expected to comply with different norms of behaviour and bodily comportment. [...] "Masculine" traits are therefore regarded as virtues in men and (often) vices in women, while "feminine" traits are regarded as vices in men and virtues in women. (Anderson, 2015)

Some groups elicit disrespect for their lack of "competence" (housewives, for example), but are liked because they are perceived as being "warm". We tend to pity these groups in ways that prompt benevolent sexism (i.e. an affectionate, but patronizing attitude suggesting that women may be nicer than men, but are weak and less competent or independent). Other groups elicit respect for their competence, but dislike for their lack of warmth (career women, for example). These groups tend to be envied and subsequent reactions are often related to forms of hostile sexism such as harassment and discrimination. Professional success may be perceived as an appealing trait in men and worrisome in women (Sandberg \& Scovell, 2013). The study by Fiske et al. (2002) shows that people identify "feminists" as being "competent", but also "cold" (i.e. disliked) and that this identity elicits hostile sexism. Feminists share this position with other female identities such as lesbians or female athletes. This type of prejudice towards women who do not conform to traditional gender roles and attributes has a long history and is recurrent in different religious and classical traditions, including the stories of Eva, Pandora, Psyche or Medusa, who all suffered social punishment due to their bright and curious minds and sense of independence. There are equally many similarities to historical Western imaginaries of witches who were perceived as autonomous and intelligent, but a danger to the community. The overall scheme that links women who demonstrate "competence" to "coldness" (i.e. being less liked) translates into multiple aspects of our life, like sexuality. Popular culture depicts feminists as 
dangerous vamps, but not bimbos. When it comes to parenthood, feminists can be mothers but may be perceived as the "cold" kind of matriarch.

This pattern places women academics in a "double bind" situation of experiencing competing demands without a clear resolution (Jenkins, 2014, p. 162). Research on gender bias shows how the agency and skills often attributed to female leaders or to feminists, such as assertiveness and being authoritative, imply that they are perceived as unfriendly (Rudman \& Glick, 2001). In comparison, a 2006 study found that "many people think that feminists are ugly, uptight, angry, aggressive, harsh, strident, demanding, dogmatic, man-hating lesbians" (cited in Weiss, 2015). It seems that the price of believing that "women are human" is a high one to pay. That is why (to paraphrase Adichie, 2014), as soon as one declares oneself to be a feminist, it is necessary to add a "but": "Hey look, I am a feminist, but I am not angry... I am the smiling feminist"; "I am a feminist, but I love babies and my grandmother"; "I am a feminist, but I love my husband and I do not hate men" or "I am a feminist, but I like lipstick, party dresses and stilettos".

Prejudice and stereotyping do not require awareness and are often "implicit". That is unwitting, unintentional and uncontrollable even among the most well-intentioned. There is increased evidence that prejudice and sexism, also in our academy, "lives and thrives in the banal workings of normal, everyday human thought and activity" (Hardin \& Banaji, 2013, pp. 13-14). Recent studies show how gender implicit bias impacts on students' teaching evaluations (Schmidt, 2015; Jackson, 2016; Boring, Ottoboni \& Stark, 2015; MacNell, Driscoll \& Hunt, 2014), the decisions of committees in charge of distributing research funds (Watson, Anderson, Hjort, 2009), the reviewing of conference papers (Roberts \& Verhoef, 2016), the evaluation of applicants' CVs (Steinpreis, Anders, \& Ritzke, 1999; Moss-Racusin, Dovidio, Brescoll, Graham, \& Handelsman, 2012), the failure to give women full credit for academic collaborative work done with men (Sarson, 2015) among many others (Savonik \& Davidson, 2016; Equality Challenge Unit, 2013).

\section{Feminist theoretical understandings and academia}

A feminist academic identity is shaped by several historical waves that have influenced feminist theorizing: the first wave being the suffragettes and the liberal movement; the second wave being socialist and radical traditions with links to the women's liberation movement - also called standpoint feminism; the third wave being the postmodern and post-structural feminists; and recently, new forms of feminism such as the transnational/cosmopolitan/post-colonial (Calas \& Smircich, 2006; Ghodsee, 2010; Swain, 2016). Parallel to these "waves" are other theoretical traditions such as psychoanalytic feminism, focused on psychosexual development, the ethics of care and women's ways of knowing, and "other" forms of feminism, such as Islamic feminism, which take points of departure that contrast Western perspectives (Eger, 2016; Narayan, 2004) The length of this article limits the scope to engage with the many feminist theoretical perspectives that are available. Therefore, I have selected forms of feminism that I have seen emerge as most prominent in the debates that took place on the Tourism Research Information Network (TRINET ${ }^{\mathrm{ii}}$ ) between 2013-2016, in the online community Women Academics in Tourism on Facebook between 2015-2016, and in a series of workshops on the topic of gender in tourism academia, which I facilitated between 2014 and 2016. The types of feminism are liberal feminism, radical/socialist feminism and postmodern feminism. 
These different theoretical perspectives can be seen in a series of studies on gender and representation in higher education. Overall, this literature indicates that there is a global underrepresentation of women as knowledge leaders (Bornmann, Mutz, \& Daniel, 2007; European Commission, 2013; Morley, 2013; UNESCO, 2012; van den Brink \& Benschop, 2012; Strid \& Husu, 2013; Watson \& Hjorth, 2015). This trend has persisted over time and across leadership categories, regardless of the cultural setting, and academic workplaces are continuing to demonstrate hierarchical gendered patterns (Husu, 2013; Benschop \& Brouns, 2003; KarataşÖzkan \& Chell, 2013). The gender situation in tourism studies mirrors that of other academic areas in the social sciences (Munar et. al. 2015). Tourism scholars have mapped the evolution of feminist thought and gender studies in tourism research production, including their impact on research topics, published works or similar (see, for example, Parry \& Fullagar 2013; Aitchison, 2005; Swain, 2016; Figueroa-Domecq, Pritchard, Segovia-Pérez, Morgan, \& Villacé-Molinero, 2015). However, with a few exceptions (Small, Harris, Wilson, \& Ateljevic, 2011; Swain, 2016), studies of what it means to adopt a feminist identity or be labelled as a feminist scholar in tourism academia are almost non-existent.

\section{Vignettes as narrative and positionality tools}

To address this topic, I combine my discussion of feminist theories and approaches with the qualitative method of the vignette. Code (2011) argues for the value of narrative and fictional accounts as effective epistemological tools; as a way of showing the Other instead of trying to provide statements or judgements about her. This fictional technique is applied here as an autoethnographic tool and narrative exercise aimed at enabling the reader to engage with feminist identities from multiple viewpoints. I work with the vignette as a narrative sketch, taking inspiration from (1) experiences in my academic life, both in activism and research, and from (2) the archetypic features of different types of feminism as presented in the literature. In this sense, the vignettes introduce and complement the explanation of feminist theoretical perspectives by acting as tableaus of self-presentation, which allow for the introduction of personal situatedness and positionality based on my lived experiences and personal reflections, and as exemplars or archetypes aimed at portraying varied feminist identities.

The context represented in these vignettes is the following: At a feminist advocacy speech on one polemic issue, the leaking pipeline of academic careers and the gap of representation of women in leadership positions in the tourism and global academy (European Commission, 2013; UNESCO, 2012; Husu, 2013; Munar et al., 2015; Pritchard \& Morgan, 2017), I present three of my feminist personalities - Sheryl-Ana the liberal, Gloria-Ana the radical/socialist, and Gaga-Ana the postmodern. Each of the vignettes is followed by an analysis of how they reflect liberal, radical/socialist and postmodern feminisms.

\section{Sheryl-Ana, the Liberal}

\section{Dear women academics,}

The statistics of academic leadership show that the higher we go the fewer women we see. This is a waste of talent and of resources for our societies. If we look at the pool of younger academics today, graduates and PhD students, we can see that there are at least as many talented women as there are men. This has been the case since the 90s, when women started outnumbering men in higher education. However, when we move upwards 
on the academic career ladder, we lose women at each step of the way with the result that it is not the most talented that move forward. Instead, what we are witnessing is a gender penalty. On the one side women become invisible - research shows that they are not scouted to take further responsibilities and that there is a homophile effect. People tend to select those who are similar to themselves and if all of those in power are men, they will tend to select men. Women are less likely to be hired for more senior positions and get less access to the people, input and opportunities that accelerate careers. On the other side, women are also pushed into taking most of the caretakers' responsibilities in relation to raising a family, and while research shows that having children is an asset for a man, for women it is a liability. There is not enough help for women to make their careers a priority, keep their ambitions and still achieve a work-life balance.

A society that aims at social progress, economic growth and to nurture its citizens' entrepreneurial spirit should not accept this status quo. There are plenty of studies that link diversity to better business results. Women can be at least as good managers and leaders as men. A feminine management style will be more team-oriented, empathic and more interactive, exactly the skills demanded by our high-speed changing markets and the information economy.

We know that women and men are different and that this difference is valuable. Women can bring other assets into the academy and the way we produce knowledge. Empowering women will increase performance levels, creativity and innovation. In our meritocratic systems of evaluation, it is women's task to lean in, to take the opportunities that are out there. More women are entering the pipeline of tourism education. If we empower women's agency and give them freedom to choose, we will see them rising into positions of power until we get a ratio between genders that really mirrors the distribution of talent in society. We need to keep and treasure our differences, but work hard to change the ratio at the top by encouraging more ambition in women and by having men academics that will support women who aim for the top.

Dear academics, make sure that you provide the empowerment that will make women's talents rise possible. On this depends our universities' capacities to achieve excellence and further competitiveness.

Dear women, it is time to lean in,

Sheryl-Ana

Liberal feminists represent both an old and new tradition: the first wave of feminism (i.e. the suffrage feminism) and the Lean-In movement (founded by Sheryl Sandberg, the chief operating officer of Facebook in 2013). The recognition of a lack of gender equality is already present in the classic writings of Mary Wollstonecraft and John Stuart Mill. Liberals believe in free selfdevelopment and are against the assumption that a women's nature is based on their commitments to family life and domestic roles. The position of women should be dependent on merit and performance and not superiority given by birth (or by sex). Liberal feminists do not want to radically change the social structures of market capitalism or modern societies, or the ways in which our universities and academic institutions are organized. They want a seat at the table where decisions are made. "We are here not because we are law-breakers; we are here in 
our efforts to become law-markers" is a known statement by Emmeline Pankhurst of the suffragist movement. One of the most popular advocates of this feminism is Sheryl Sandberg (Sandberg \& Scovell, 2013). Feminist liberals stress the importance of freedom to choose and individual agency versus the power of social structures. They aim at achieving participation in power, emphasize equality metrics and the removing of obstacles for women to advance in their careers. Inspired by liberal ideologies they fight for what also has been called "capitalist equality" and celebrate the individual achievement over the collective (Oloresnshaw, 2016a).

Their understanding of the concept of "gender" is associated with what has been popularly called "women's issues" and "gender roles". As explained by Wood and Eagly, "beliefs about the traits of women and men-track the division of labour because people infer these traits from their observations of the sexes' behaviours. Social perceivers often essentialize these traits by regarding them as inherent in the biology or social experience of women and men" (2012, p. 56). There is an array of studies on women's behaviour which highlight a conflict between the attributes stereotypically associated with femininity and those traditionally associated with leadership (Baxter, 2006; Holmes \& Schnurr, 2006). These gendered norms are embedded in everyday workplace interaction, shaping people's perception of power and their judgement of what is appropriate or inappropriate. For example, the study by Cross, Rebele and Grandt (2016), who write about collaboration in the workplace, show that

The lion's share of collaborative work tends to fall on women. They're stereotyped as communal and caring, so they're expected to help others with heavy workloads, provide mentoring and training to more junior colleagues, recruit new hires, and attend optional meetings. As a result, the evidence shows, women experience greater emotional exhaustion than men. (p.79)

Liberal feminists try to reverse these negative discourses by emphasizing the value that organizations can get from investing in feminine attributes and point to the similarities between these and advanced fluid capitalism (Gerzema \& D'Antonio, 2013).

In higher education and scholarship, the focus on vertical segregation and "getting a seat at the table" is reflected in efforts to map the gender ratio of leadership indicators, for example in the statistical reports such as the European Commission's (2013) "She Figures" or the "Gender Gap in the Tourism Academy" (Munar et al., 2015). This emphasis can also be seen in academic policy strategies on talent development and talent progression. Such policies often rely on three major assumptions: first, that academic systems are meritocracies where effort and merit are rewarded with increased authority and benefits; second, universities are seen as organizations made up of autonomous actors whose goal is to make their institutions more efficient and fair; and third, this logic takes for granted that there is an "ideal academic" or "the ideal academy" (as something that is universally valid) and that given the necessary freedom and agency, men and women can strive to achieve this ideal by means of their individual rationality and will. Additionally, policies related to liberal feminism emphasize mentorship programmes and initiatives that empower women to self-promote and feel good about being "ambitious like a man".

This "liberal" feminist logic and its discourse is what I see as being prioritized at the moment in many of the diversity/inclusion reports and discourses in universities, including my own. A good example of this tendency is the title of the report "Getting All Talents in Play", 
published by the Danish National Research Foundation in 2015. Another recent report from Copenhagen Business School that examines and analyses gender and leadership practices (e.g. recruitment, promotion, scouting) shows that academic managers maintain a strong belief in academic meritocracy and in academia as a just, "neutral" system located outside or parallel to society, but whose organizational participants (students, staff) are still affected by it (Munar \& Villèseche, 2016). Paradoxically, the main pillar of the belief in meritocracy is the premise that we have systems and cultures that are essentially unbiased and that appointments, rewards and recognition are based upon objectively definable elements such as excellence or talent. There is thus the assumption that individual career progression follows "merit" and that there is no bias, with reality being mirrored in a perfect (literal) way. It is the dream of objectivism in science transferred to objectivism in academic career progression.

A critique voiced by other feminist positions is that advocates of liberal feminism seldom address the interests of other groups beyond white, middle class educated women (Falcón \& Nash, 2015). Nancy Fraser has described these types of feminists as "the handmaids of capitalism" (Fraser in Oleranshaw, 2016b). But, as indicated by Calas and Smircich (2006), the feminist liberal position seems to be unable to move gender issues beyond a conversation of "women being as good as men" or "women's difference" as an asset for organizational performance and growth.

\section{Gloria-Ana, the Radical/Socialist}

Dear colleagues,

The women's liberation movement has achieved profound gains in economic, social and legal terms. However, to date none of the many economic indicators for the world as a whole shows equality between men and women and, regardless of whatever explanation is given for this situation, this is what the reality looks like. People tend to say that equality is just around the corner, but if there is something we can learn from decades of feminist activism, it is that either we aim for a profound transformation of patriarchal social structures or change will not happen.

This is not about putting the blame on academic women because they lack ambition or to teach them to "dress for success". It is about changing the way we think about what a good academy and a successful academic career are. The truth is that no matter how much we try, our ways of being and doing in academia are affected by our bodies and by the way we have been socialized since our early years. From the way popular culture portrays women and the feminine (e.g. the emphasis on beauty and erotic capital instead of intelligence or courage) to the moral codes of what it means to be a good mother or a good partner, these norms lie deep in our flesh and our unconscious. We have been trained to identify good academic leadership by traditional masculine values competition, determination and individuality.

The truth is that women are "sex classed" - an oppressed class that has learned to appreciate being oppressed. Our gender - all that encompasses the feminine - is not an essence that is given to us at birth, but a social construction; a system that ensures the continuation of the subordination of women to men in all spheres of life from the private domain to the public. Our societies and capitalism have always valued production (where 
men have historically been dominant) over reproduction (which has biologically and socially been the woman's domain). Women suffer exploitation because their labour activities related to care and the home have been taken for granted, made invisible and non-capitalized.

This is a deep historical injustice that keeps half of the world's population in visible and invisible chains and it should not be tolerated. But we can do something about this. A necessary step to a better future for women starts with claiming the rights over our own bodies and the appreciation of women's work. The good academy is a non-patriarchal academy. Our fight is not to be like men, act like men and get to the top to reproduce a system that is rooted in gendered exploitation. We do not need suits or to play our femininity card to become objects of desire. What we need is an academy based on principles like the ethics of care and not the ethics of performance; an academy that is less hierarchical, more open and nurturing and that allows for envisioning and valuing collaboration over competition. We do not want to lean in to further fuel a capitalist system that is based on the exploitation of the people and resources of this planet, and that fosters greater wealth inequality.

My dear colleagues, let's strive for our universities to become agents of emancipation, and forces for changing the injustices of the societies around us. We need to create new institutions and re-think what good academic careers are by moving beyond traditional masculine values of management. We should tear away those suits of oppression and reclaim the freedom of our bodies. It is time to liberate yourself from the indoctrination of our patriarchal societies and take action for a new academy that aims for justice, equality and care for our fellow human beings and for our common mother earth.

\section{Gloria-Ana}

In the radical socialist tradition, gender is understood as a system of male domination (Calas \& Smircich, 2006, p. 21). Experiences such as sexism or failing to promote in academia are seen as a consequence of systems where the male and masculinity are considered the norm, and not as an individual failure. Due to its connection to the women liberation movement (from the $60 \mathrm{~s}$ onwards), social-radical feminism has been predominant in a lay/popular understanding of the word "feminist", and lies behind many of the prejudices mentioned earlier. This type of feminist may be considered as competent, but not likeable, and therefore elicit forms of hostile sexism (Fiske, Cuddy, Glick, \& Xu, 2002).

Characterized by standpoint theory, this feminism argues that knowledge is grounded in one's social position, and it makes us aware of how privileged groups in society may represent social phenomena only in relation to the interests of the privileged class, but still believe that these representations coincide with universal human interests (e.g. by presenting "the masculine" as a complete representation of "the human"). Standpoint theory and the situatedness of knowledge (one of the "most fruitful and heavily debated areas of theorizing for feminist epistemologists", Grasswick, 2013), allow the recognition of sexism and androcentrism in what was previously considered as objective knowledge production. Radical and socialist feminism are types of critical theory (as understood by the Frankfurt school). Critical theories aim to 
“a) represent the world in relation to the interests of the oppressed; (b) enable the oppressed to understand their problems; and (c) be useable by the oppressed to improve their condition. Critical theory is theory of, by, and for the subjects of study" (Anderson, 2015).

And as a result "even if a particular feminist theory cannot make good on the claim that it has privileged access to reality, it may offer true representations that are more useful to women than other true representations" (Anderson, 2015).

This type of feminist stresses that in many places around the world women still lack basic political rights, equal access to education, basic reproductive rights, opportunities to achieve economic independence, or something as simple as opening a bank account and getting a passport without the permission (signature) of a male guarantor. While the focus of socialist feminism has mainly inspired concerns for women's alienation through labour and class inequalities, gendered cultures and the female body have also played key roles in the radical tradition. For radical feminists, the body is political and women's alienation happens through sexual objectification and a female identity constituted by men's desire. Bodies are the places where the battle of liberation is fought. A contemporary example of this feminism is the activist group FEMEN:

All functions of the female body are harshly controlled and regulated by patriarchy. Separated from the woman, her body is an object to monstrous patriarchal exploitation, animated by production of heirs, surplus profits, sexual pleasures and pornographic shows. Complete control over the woman's body is the key instrument of her suppression; the woman's sexual demarche is the key to her liberation. Manifestation of the right to her body by the woman is the first and the most important step to her liberation. (FEMEN, 2016)

Socialist and radical feminists claim that institutions and societies that proclaim to be "gender neutral" are instead "gender blind" and help reproduce systemic biases against women in policy thinking (Nakray, 2014, p. 252). From this perspective, it is not enough to be a "woman" because women in patriarchal systems may defend and support inequality. There has to be a raising of consciousness among women if they are to recognize the injustice of dominant ideologies and power systems. Advocates of this feminism point out that "traditionally the goals of social policy were to achieve the goals of social justice and equality however all across the world today social policy debates are highly cynical and politicized and are largely ideologically shifted to redistribution of resources in favour of managing risks and improving productivity of the people" (Nakray, 2014). A series of recent theoretical schools, such as post-colonial feminism, are historically linked to the second wave tradition, but depart from it in several ways (Narayan, 2004). First, these feminists show a stronger emphasis on intersectionality and positionality. Intersectionality focusses on the experiences of the multiple-marginalized and allows seeing how certain structures collaborate and collude to produce positions of marginalization (Falcón \& Nash, 2015).

Looking at the academic world, this type of feminism denounces that the "corporate university" focuses on diversity, as long as it does not entail major structural changes. Diversity management appears as a form of "diversity greenwashing" and women of colour are trapped in a paradoxical situation: "to be at once valuable for our imagined diversity and to be devalued for 
our imagined insistence on identity politics" (Falcón \& Nash, 2015, p.8). Patriarchies go handin-hand with market capitalism and exploitative globalization. In the words of Bella Abzug (a key figure of the liberation movement in the US), feminism is not about replacing a "white, middle-class elite with a white, female, middle-class elite", it is about "transforming the system not imitating it" (Steinnem, 2015, p.358). Universities and our academic cultures are part of these structures and contribute to the reproduction of such elite systems, by, for example, following the rules of market capitalism in their justification of educational programmes, identification of research problems and evaluation of knowledge impact.

Female academics' discourses about work-life balance also respond to gendered attitudes about paid work and unpaid care (Toffoletti and Starr, 2016) in a similar way to the gendered values and perspectives that can be seen in hospitality (Veijola and Jokinen, 2008). For the socialist feminist, justice is not only about ratio equality (or more women at the top), but about solidarity, self-determination and the recognition of unpaid labour:

We talk about the boardroom, not the birthing room. We talk about the feminization of poverty without stopping to acknowledge that a significant reason women face poverty is because we still refuse to put money in their hands to reflect the valuable work they do. The unwaged work of children and home. (Olorenshaw 2016, p.2)

Radical feminists are wary of formal mentoring programs and other initiatives that they see as interventions to "fix the women" or to "add women and stir" and whose focus is on improving performance by assimilating women into dominant masculine corporate cultures, while avoiding major collective or structural solutions (Colley 2001 cited in Morley, 2013, p. 125). For these feminists, it is not about fixing but about rethinking. Radical/Socialist feminists in the academy acknowledge that it is not enough for universities to maintain a system that allows the exercise of scholars' individual rights; our academic institutions need to recognize that the problem is also in the premises and structures of the institutions which discriminate and disadvantage particular groups in society (according to gender, class, race, sexuality, etc.). They consider academic institutions to be non-neutral hierarchical organizations. Management practices of academic "meritocracies" (e.g. of recruitment, promotion and networking) are seen as producers and reproducers of attitudes, traditions and norms that allow gender discrimination and privilege the "man" and the "masculine" as the norm. To say it briefly, radical feminists question whether achieving power and status in such a system merely serves the reproduction of injustice.

This feminism is based on the belief that there is no universal ideal of the "good" academic, but that academic work is embodied, positional and contextual. It is not about climbing the academic career ladder, but about dismantling the ladder itself and finding new practices and ways of constructing knowledge and establishing new academic institutions that do not have sexism, classism or other forms of discrimination embedded in their academic practices. Examples of this tendency are works and movements against the neoliberal university (Ayikoru, 2014; Collini, 2012; Falcón \& Nash, 2015; Giroux, 2014), critiques of the "leaderist turn" in academia (i.e. the re-orientation of public services towards the consumer citizen) (Morley, 2013), strategies against the dominance of the "systemic paradigm" of marketization and bureaucratization of academic life spaces and life worlds (Munar, 2016), critiques of the emphasis on quantification, key performance indicators and rankings (Ryan, 2012), demands for a more inclusive tourism curriculum (Chambers, 2015), the promotion of "slow scholarship" 
(Berg \& Seeberg, 2016) and alternative visions for a more just and equitable academy like those represented by the academy of hope (Pritchard et al., 2011), the humanist paradigm (Caton, 2016), and the embodied cosmopolitan paradigm (Swain, 2016). These understandings can be seen in fluid networks that shape an alternative academy. Examples of these include Equality in Tourism, Critical Tourism Studies, the Tourism Education Futures Initiative, Women Academics in Tourism, among others.

\section{Gaga-Ana, the Postmodern}

Hi wonderful people

Yes, those statistics suck. It is incredible that there are no more women as academic leaders in the tourism academy. But to be honest, I know women who are more masculine than some of my male friends. They are all about competition and getting there no matter what cost. I was discussing this the other day with my partner, because we want to share the parental leave when our baby is born, but when he mentioned it to Laura, his Head of Department, she asked him if he was unhappy at work - can you believe that?

Now it seems that men who want to spend time with their babies only do that if they are unhappy at their work place. When the truth is that Peter loves his work, and so do I, we both love it, but he also wants to have time with our baby. It's not like we are going to have five children, right? And it is now or never - when are we going to have the opportunity to enjoy this experience in life?

We had plans to spend some of these months together in Majorca, where I did my PhD fieldwork. It is cheaper than here and the weather is so much better than the Danish winter for a baby. I wanted to use some of the time to continue with my work there. I had already written to my friends of the tourism community development project and they were looking forward to seeing me again. Sarah, my best friend, was going to take a few weeks off from her university in Toronto and come to stay with us so we could write together... and Peter just wanted to focus on the baby and learn Spanish cooking. He is so much better at that than me... and then he had this cool idea about starting a blog about being an academic father which he could use as an autoethnographic project.

But instead all our plans are now ruined!

It seems that only one of us can take parental leave and that will have to be me if I am going to be breast feeding (although I may still change my mind about that). Peter will have to be teaching and going to the office, so no Majorca for us. Instead of doing fieldwork and writing with Sarah, I will be alone in my small apartment in Copenhagen. Isolated and at 3 degrees in November, there is nothing that can be more demotivating. And who thinks up those norms? It is all these men at the top who never in their lives thought of taking any parental leave, and these women who have managed to get to the top by becoming exactly like these men, but being even harder... and now Peter is expected to live up to this "macho" academic ideal, where the only thing he can think of is his next career move. And who cares about making it to the top of our universities, really? Have you been around the managers of universities recently? Most of the time I am dying of boredom. Peter and I have found our inspiration elsewhere. My dream is to 
start a tourism cosmopolitan academy with all the awesome creative researchers that I know; no more titles or departments, just us and our students working on research projects we are passionate about and collaborating with local communities, artists, creatives, environmentalists, planners... making a real difference and having fun.

But this dream will have to wait. Right now I am mostly worried about how to manage taking care of our baby on my own and what this will mean for all the projects that I am engaged in.

But hey, it's not like I am going to shut up about this, right? And neither should you. My friend Dezmond, who is an amazing designer, and I have created a social media hashtag campaign called \#lovingacademicdads. Please, all of you, it will only take you a second to share the love in your social media networks. And on Friday we have organized a launch of the campaign where we will all dress pink - it will be awesome. Come and join us and let's dismantle this old sexist academy and walk into a brand new era!

Hugs and kisses to you all,

Gaga-Ana

Post-modern feminism took off during the 1990s. Inspired by the postmodernism movement (i.e. a variety of theorists such as Derrida, Foucault and Lyotard), it rejects totalizing metanarratives that try to capture the "truth" about the world, and instead claims that reality is discursively constructed. It stresses the contingency, locality, uncertainty and contestability of any account of the world, the self and the good (Anderson, 2015; Harvey, 1989). Postmodernists challenge universalism, objectivism and the overall scientific tradition following the Enlightenment. Postmodern feminism gives priority to the power of discourse. It puts subjectivity at the centre and rejects the fixity of identity, and, accordingly, it advances a critique of the concept of "woman", which was the central analytical category in the other feminist traditions (Anderson, 2015). For Haraway (1991, p. 155), "(t)here is nothing about being 'female' that naturally binds women". The concern here is not how gender is done, but what the conditions are for such "doing" and what the consequences are of these "doings". Therefore, it stresses the importance of the "performativity of gender" (Butler, [1990]1999) and enhances the recognition of affinity instead of identity (Haraway, 1991, p. 155). Key representatives of this tradition advocate a move beyond "standpoint theory" (i.e. the emphasis on situatedness) towards a strong antiessentialism.

Inspired by queer movement and scholarship, the focus on the body continues to be very important in this tradition, too, but the interest expands further from gender into sexuality. Body and gender are not seen as fixed, but as flexible with concepts like "mobility" and "becoming" taking centre stage and displacing "essence" and "being" (Calas \& Smircich, 2006). Botterill and I reflected on the need to recover the embodiment and emotionality of academic lives during the dialogue keynote speech titled "On Being an Academic" at the annual conference of the Association for Tourism in Higher Education (Edinburgh, December 2014):

[Academic careers] run deep inside our bodies. They are nothing like a nicely structured $\mathrm{CV}$ or the operational tales of team collaboration and networking. It is often about power, interests, and passions. Sometimes (many more times than we will ever dare to 
recognize) what makes people optimistic about their field it is not the 'field' itself, it can be things like being in love with someone and feeling that life is worth living and fighting for (Munar's discourse in Munar \& Botterill, 2014).

Pernecky expresses the power of fluidity, becoming and the subjective in his account of postdisciplinarity in academia: "After all, do we not take part in many fleeting versions of the worlds we occupy? There does not have to be only one all-encompassing interpretation of all that exists"; and Wheeller states that "research is moulded by prosaic resource and temporal considerations. And, of course, the researcher's personality, profile and perspectives are paramount. Acknowledging and accepting this, surely we can accommodate (and celebrate) 'the personal' as a positive" (Pernecky's and Wheeller's personal narratives in Pernecky, Munar \& Wheeller, 2016).

Postmodern gender studies examine gender heterogeneity and emphasize that social reality is unstable and ambiguous. Postmodern feminists like radical/socialist feminists also adhere to denouncing the privilege of an enlightened modernity that presumes to speak for others (for example, when male academic leaders speak for "all" of the academy). Additionally, they criticize the idea that women and men have innately different leadership positions (with men being by "nature" focused on productivity, competitiveness, hierarchy and strategy, and the "woman's advantage" being advanced communication skills, empathy and relationality). Such propositions are dualistic and essentialist (i.e. a naturalization of female and masculine traits), and create bindings for women or men who do not fit the "gender scripts". Scholars such as Muhr (2011) and Billing (2011) have criticized this dualistic logic and ask "in what sense do work practices and norms still reflect the life situations and interests of men?" (Morley 2013, p. 124). A good example of such a polemic is "The Parent Career Scientist" initiative of the Royal Society in the UK, which goes against the "greedy organization" and "carefree logic" in universities and, according to their website, "celebrates the diversity of work life patterns of 150 scientists across the UK with the aim of increasing the visibility of people combining a career in science with a family life" (Royal Society, 2016).

However, the postmodern position has received its share of criticism. According to Anderson (2015), the rejection of "woman" as a category of analysis and the infinite fragmentation of experiences is controversial:

That women in different social positions may experience sexism differently does not entail that they have nothing in common - they still suffer from sexism (MacKinnon 2000) [...] fragmentation and multiplicity threatens both the possibility of analytical focus [...] and of politically effective coalition building among women with different identities. (Anderson, 2015)

In a postmodern spirit, we could say that the word "feminist" suffers from the same problem as the word "woman". As the previous analysis of definitions and theoretical traditions shows, there are multiple ways in which one could reasonably answer what it means to be a feminist. Feminist identity appears as a vast kaleidoscope of possible discourses and understandings. However, it is worth reflecting on Anderson's (2015) critique of the limits of postmodernism. The existence of individual and subjective realities does not detract from the possibility of common and shared social phenomena such as sexism or racism. 


\section{Conclusion and implications}

The three characters I featured in my vignettes follow different knowledge traditions which lead them to pursue different types of activism and political engagement. However, the key question remains: If I am to be defined as a feminist academic - then what am I? After all this reading and analysis I have far from reached a certain or "appropriate" feminist understanding or a definite path of action, but I have come much closer to what I understand as my feminist identity. I could summarize it by saying that it is a complex combination of critical and postmodern traditions with an appreciation for the celebration of agency of the liberal school. I believe that to address gender inequality in tourism academia, what we need is a mix of 1) a focus on the liberating capacity of personal agency and freedom of the liberal school. Agency seen not as a search for vertical career success adapted to established managerial practices, but as a celebration of an entrepreneurial drive that strives to create new ways of creating knowledge and educating; 2 ) the emphasis of the critical scholarship on justice (the indignation about inequity and oppression), its focus on solidarity, and the belief in the power of collective action (e.g. legal change and political activism); and (3) the playfulness of the postmodern and its focus on the subjective and processual (i.e. the personal emphasis in becoming instead of being; the critique of essentialism). A celebration of the postmodern idea that gender emancipation entails the emancipation of both men and women (rethinking the gender roles that act as identity cages). A form of feminism where men are not seen as the "opposition", but actually as partners in envisioning other possible ways of doing knowledge and being an academic, and where our universities are not developed as careless but as caring institutions.

This essay is an invitation to embrace the possibilities of becoming and the co-existence of multiple ways of being and doing in academic feminism. At the same time it is a call to be vigilantly aware of a postmodern position that can undermine our capacity of collective action and political engagement. Cognition is always autobiographical and emotional, and any research activity starts with a personal research act. However, sense-making has a strong social element, languages are social systems, and we understand by interacting with others in specific social contexts. There is a passionate beauty in Foucault's call to eliminate the fascism in our heads by exploring and building on the open qualities of human discourse, and thereby intervening in the way knowledge is produced and constituted at the particular sites (our universities or academic institutions) where a particular power discourse prevails. The danger of emphasizing infinite fragmentation of positions due to social differentiation and embodiment is to advance a form of narcissistic self-liberation that abandons the world of the commons because it stopped believing in shared solutions or understandings of the "good" or "just" in the world. Postmodern feminism is in love with the aesthetics of life (life as art), while radical/socialist feminism is in love with the politics of life (life as action). Both need each other. If they remain separate the former may end up in narcissistic localized lifestyles and the latter in judgmental totalizing worldviews.

A large amount of evidence shows an academic reality that disadvantages women. Adopting a critical theory standpoint, our purpose has to be to act and conduct research of, by, and for the subjects of oppression. So how can women be supported to achieve their aspirations and flourish in our tourism academy? First and foremost we need self-reflexivity and consciousness-raising initiatives, and second to implement a large variety of policy tools adapted to specific academic environments; from mentoring schemes, quotas, strategies to counteract implicit biases, guidelines to change the ratio of everything we do - from speakers in 
conferences to committees and editorial teams, new role models, and increase the visibility and appreciation of diverse ways of leading and being an academic.

I would like to finish with one of my favourite definitions of what it means to be a feminist. It is by the author Chimamanda Ngozi Adichie:

A feminist is a man or a woman who says "yes, there is a problem with gender as it is today and we must fix it, we must do better". (Adichie, 2014, p. 48)

But now you are warned - to be called a feminist is a powerful and challenging thing. So yes, I am a feminist. Feel free to dislike me, although if you have time to continue this conversation with me over a cup of coffee, you may discover that I am feminist and also kind.

\section{References}

Adichie, C. N. (2014). We should all be feminists. London: Fourth Estate.

Aitchison, C. C. (2005). Feminist and gender perspectives in tourism studies. The social-cultural nexus of critical and cultural theories. Tourist Studies, 5(3), 207-224. doi: 10.1177/ 1468797605070330

Anderson, E. (2015). Feminist Epistemology and Philosophy of Science. In Stanford Encyclopedia of Philosophy (2015ed.). Retrieved 3 November, 2016 from http://plato.stanford.edu/entries/feminism-epistemology/

Ayikoru, M. (2014). Neoliberalism and the New Managerialism in Tourism and Hospitality Education. In D. Dredge, D. Airey, \& M. Gross (Eds.), The Routledge Handbook of Tourism and Hospitality Education (pp. 118-129). London: Routledge.

Baxter, J. (Ed.) (2006). Speaking out: The female voice in public contexts. London: Springer.

Benschop, Y., \& Brouns, M. (2003). Crumbling Ivory Towers: Academic Organizing and Its Gender Effects. Gender, Work and Organization 10(2), 194-212.

Berg, M., \& Seeberg, B. (2016). Slow Professor: Challenging the Culture of Speed in the Academy. Toronto: University of Toronto Press.

Billing, Y. D. (2011). Are Women in Management Victims of the Phantom of the Male Norm? Gender, Work \& Organization, 18(3), 298-317. doi:10.1111/j.1468-0432.2010.00546.x

Bornmann, L., Mutz, R., \& Daniel, H. D. (2007). Gender differences in grant peer review: A meta-analysis. Journal of Informetrics, 1(3), 226-238. doi: 10.1016/j.joi.2007.03.001

Butler, J. ([1990]1999). Gender trouble: feminism and the subversion of identity. Abingdon: Routledge.

Calas, M., \& Smircich, L. (2006). From the "Woman's Point of View" Ten Years Later: Towards a Feminist Organization Studies. In S. Clegg, C. Hardy, T. Lawrence, \& W. Nord (Eds.), The SAGE Handbook of Organization Studies (2nd ed., pp. 284-346). London: Sage. doi:10.4135/9781848608030.n9

Caton, K. (2012). Taking the moral turn in tourism studies. Annals of Tourism Research, 39(4), 1906-1928. doi:10.1016/j.annals.2012.05.021

Caton, K. (2016). A Humanist Paradigm for Tourism Studies? . In A. M. Munar \& T. Jamal (Eds.), Tourism Research Paradigms: Critical and Emergent Knowledges (pp. 35-56). Bingley: Emerald.

Chambers, D. (2015). Inclusivity in tourism higher education: accessing worlds and knowledges otherwise. In A. M. Munar, T. Pernecky, \& T. Hvar (Eds.), 2nd Tourism Postdisciplinarity Conference: Freedom. Art. Power (p. 17). Copenhagen. Retrieved 5 August, 2015 from http://media.wix.com/ugd/6c0934_10191d7de6c94340a16b83adf24ef388.pdf 
Code, L. (2011) "They treated him well": Fact, Fiction, and the Politics of Knowledge. In H. E. Grasswick (Ed.), Feminist Epistemology and Philosophy of Science (pp. 205-222). London; New York: Springer.

Collini, S. (2012). What Are Universities For? London: Penguin Books.

Cross, R., Rebele, R., \& Grandt, A. (2016). Collaborative overload. Harvard Business Review. (January-February, 2016 Issue). Retrieved 10 June, 2016 from http://web.b.ebscohost.com/ehost/pdfviewer/pdfviewer?vid=1\&sid=cf1 8ad25-6bd0-4e599e06-323327531082\%40sessionmgr2

Eger, C. (2016). Empowerment through education: Tour operators promoting gender equality through capacity building in destination communities (Unpublished Doctoral Thesis). University of Surrey, Guilford, United Kingdom.

Equality Challenge Unit. (2013). Unconcious Bias in Higher Education. Retrieved 5 April, 2015 from http://www.ecu.ac.uk/wp-content/uploads/2014/07/unconscious-bias-and-highereducation.pdf

European Commission. (2013). She Figures 2012: Gender in Research and Innovation. Brussels: Publications Office of the European Union.

Falcón, S. M., \& Nash, J. (2015) Shifting analytics and linking theories: A conversation about the meaning-making of intersectionality and transnational feminism. Women's Studies International Forum, 50, 1-10. FEMEN (2016). About us. Retrieved 10 December, 2016 from http://femen.org/about-us/

Figueroa-Domecq, C., Pritchard, A., Segovia-Pérez, M., Morgan, N., \& Villacé-Molinero, T. (2015). Tourism gender research: A critical accounting. Annals of Tourism Research, 52, 87-103. doi:10.1016/j.annals.2015.02.001

Fiske, S. T., Cuddy, A. J. C., Glick, P., \& Xu, J. (2002). A model of (often mixed) stereotype content: competence and warmth respectively follow from perceived status and competition. Journal of Personality and Social Psychology, 82(6), 878-902. doi:10.1037/0022-3514.82.6.878

Foucault, M. (1995) Discipline and Punish: The Birth of the Prison. New York: Vintage Books.

Foucault, M. (2000). Power, In James D. Faubion (Ed.).Power. New York: New Press.

Gerzema, J., \& D'Antonio, M. (2013). The Athena doctrine: How women (and the men who think like them) will rule the future. Hoboken: John Wiley \& Sons.

Ghodsee, K. (2010). Revisiting the United Nations decade for women: Brief reflections on feminism, capitalism and Cold War politics in the early years of the international women's movement. Women's studies international forum, 33, 3-12.

Giroux, H. A. (2014). Neoliberalism's War on Higher Education. Chicago: Haymarket Books.

Grasswick, H. E. (2011). Introduction: Feminist Epistemology and Philosophy of Science in the Twenty-First Century. In H. E. Grasswick (Ed.), Feminist Epistemology and Philosophy of Science (pp. xiii-xxx). London; New York, NY: Springer.

Grasswick, H. E. (2013). Feminist Social Epistemology. In The Stanford Encyclopedia of Philosophy (Spring 2013 Edition) (Zalta, N.). Retrieved 5 April 2016, from http://plato.stanford.edu/archives/spr2013/entries/feminist-social-epistemology/

Habermas, J. (1989). Theory of communicative action 2 (Vol. 2). Boston, MA: Beacon Press.

Haraway, D. (1991). Simians, cyborgs, and women: The reinvention of nature. New York: Routledge. 
Harding, S. G. (1986). The science question in feminism. Ithaca; London: Cornell University Press

Hardin, C. D., \& Banaji, M. R. (2013). The Nature of Implicit Prejudice: Implications for Personal and Public Policy. In E. Shafir (Ed.), The Behavioral Foundations of Public Policy (pp. 13-31). Princeton: Princeton University Press.

Harvey, D. (1989). The Condition of Postmodernity: An Enquiry into the Origins of Cultural Change. Oxford: Blackwell.

Holmes, J., \& Schnurr, S. (2006). "Doing femininity" at work: More than just relational practice. Journal of Sociolinguistics, 10(1), 31-51. doi: 10.1111/j.13606441.2006.00316.x

Husu, L. (2013). Interrogating Gender Paradoxes in Changing Academic and Scientific Organisation(s). In S. Strid \& L. Husu, Eds. GEXcel Work in Progress Report Volume XVIII. Proceedings from GEXcel Themes 11-12 Visiting Scholars: Gender Paradoxes in Changing Academic and Scientific Organization(s). Retrieved 4 August, 2017 from http://www2.warwick.ac.uk/fac/soc/sociology/staff/academicstaff/mariadomarpereira/gexce 1.pdf

Jackson, S. M. (2016). The Influence of Implicit and Explicit Gender Bias on Grading, and the Effectiveness of Rubrics for Reducing Bias (Doctoral dissertation). Wright State $\begin{array}{lllll}\text { University. } & \text { Retrieved } & 8 & \text { January, } & 2017\end{array}$ https://etd.ohiolink.edu/!etd.send file?accession=wright1464731201\&disposition=inline.

Jenkins, K. (2014). "That's not philosophy": feminism, academia and the double bind. Journal of Gender Studies, 23(3), 262-274. doi: 10.1080/09589236.2014.909720

Karataş-Özkan, M, \& Chell, E. (2015). Gender Inequalities in Academic Innovation and Enterprise: A Bourdieuian Analysis. British Journal of Management 26(1), 109-125. doi:10.1111/1467- 8551.12020.

Kramarae, C., Treichler, P. A., \& Russo, A. (1992). Amazons, bluestockings and crones: a feminist dictionary. London: Routledge..

MacNell, L., Driscoll, A., \& Hunt, A. N (2014). What's in a name: Exposing gender bias in student ratings of teaching. Innovative Higher Education40, 291. doi:10.1007/s10755014-9313-4

Morley, L. (2013). The rules of the game: women and the leaderist turn in higher education. Gender and Education, 25(1), 116-131. doi:10.1080/09540253.2012.740888

Moss-Racusin, C. A., Dovidio, J. F., Brescoll, V. L., Graham, M., \& Handelsman, J. (2012).

Science faculty's subtle gender biases favour male students. Proceedings of the National Academy of Sciences for the United States of America, 109(41), 16474-16479.

Munar, A. M., Biran, A., Budeanu, A., Caton, K., Chambers, D., Dredge, D., Gyimóthy, S., Jamal, T., Larson, M., Nilsson Lindström, K., Nygaard, L., Ram, Y. (2015). The Gender Gap in the Tourism Academy: Statistics and Indicators of Gender Equality. Copenhagen. Retrieved 8 September, 2016, from http://openarchive.cbs.dk/handle/10398/9178

Munar, A. M., \& Botterill, D. (2014, December). On Being an Academic. Keynote paper presented at the Annual Conference Association of Tourism Higher Education, Edinburgh.

Munar, A. M. (2016). The House of Tourism Studies and the Systemic Paradigm. In A. M. Munar \& T. Jamal (Eds.), Tourism Research Paradigms: Critical and Emergent Knowledges (pp. 131-153). Bingley: Emerald. doi: 10.1108/S1571-504320150000022014

Munar, A. M., \& Villesèche, F. (2016), Gender and Academic Leadership Practices at Copenhagen Business School. Copenhagen Business School, Frederiksberg, Denmark. Retrieved 10 November, 2016, from 
http://research.cbs.dk/files/45082365/GENDER_AND_ACADEMIC_LEADERSHIP_PR ACTICES AT CBS final 20Sept .pdf

Muhr, S. L. (2011). Caught in the Gendered Machine: On the Masculine and Feminine in Cyborg Leadership. Gender, Work \& Organization, 18(3), 337-357. doi:10.1111/j.14680432.2010.00529.x

Nakray, K. (2014). Rethinking gender and social policies: In the changing contexts of development across the world. Women's Studies International Forum, 47, 250-254.

Narayan, U. (1997). Dislocating cultures: identities, traditions, and Third-World feminism. New York: Routledge.

Narayan, U. (2004). The Project of Feminist Epistemology: Perspectives from a Nonwestern Feminist. In S. G. Harding, The feminist standpoint theory reader: Intellectual and political controversies, pp. 213-224. New York: Routledge.

Olorenshaw, V. (2016a). Liberating motherhood. Cork: Womancraft Publishing.

Olorenshaw, V. (2016b). Viewpoint: Liberating motherhood and the need for a maternal feminism. Discover Society. Retrieved 24 October, 2016 from $\mathrm{http}: / /$ discoversociety.org/2016/03/01/viewpoint-liberating-motherhood-and-the-need-for-amaternal-feminism/

Oxford Dictionary (2016). Feminist - definition of feminist in English. Retrieved 11 December, 2016 from http://www.oxforddictionaries.com/definition/english/feminist

Parry, D., \& Fullagar, S. (2013). Feminist Leisure Research in the Contemporary Era. National Recreation and Park Association, 45(5), 571-582.

Pernecky, T., Munar, A. M., \& Wheeller, B. (2016). Existential Postdisciplinarity: Personal Journeys into Tourism, Art, and Freedom. Tourism Analysis, 21(4), 389-401. doi: $10.3727 / 108354216 \mathrm{X} 14600320851730$

Pritchard, A., Morgan, N., \& Ateljevic, I. (2011). Hopeful tourism: A new transformative perspective. Annals of Tourism Research, 38(3), 941-963 doi:10.1016/j.annals.2011.01.004

Pritchard, A., \& Morgan, N. (2017). Tourism's lost leaders: Analysing gender and performance. Annals of Tourism Research, 63, 34-47. doi: 10.1016/j.annals.2016.12.011

Royal Society (2016). Parent career scientist campaign. Retrieved 20 October, 2016 from https://royalsociety.org/topics-policy/diversity-in-science/parent-carer-scientist/

Rudman, L. A., \& Glick, P. (2001). Prescriptive Gender Stereotypes and Backlash Toward Agentic Women. Journal of Social Issues, 57(4), 743-762. doi: 10.1111/00224537.00239

Ryan, S. (2012). Academic zombies. A failure of resistance or a means of survival? Australian Universities' Review, 54(2), 3-11.

Sandberg, S. \& Scovell, N. (2013). Lean In: Women, Work, and the Will to Lead. Random House.

Savonik, D., \& Davidson, C. N. (2016). Gender Bias in Academe: An Annotated Bibliography of Important Recent Studies. Retrieved 7 January, 2017 from http://blogs.lse.ac.uk/impactofsocialsciences/2016/03/08/gender-bias-in-academe-anannotated-bibliography/

Schmidt, B. (2015). Gendered Language in Teacher Reviews. Bookworm Project, February, 41. Retrieved 8 January, 2016 from http://benschmidt.org/profGender/\#

Sebestyen, A. (2016, March 1). Focus: The difference between feminism and women's 
liberation. Discover Society. Retrieved 10 October, 2016 from http://discoversociety.org/2016/03/01/focus-the-difference-between-feminism-and-womensliberation

Small, J., Harris, C., Wilson, E., \& Ateljevic, I. (2011). Voices of women: A memory-work reflection on work-life dis/harmony in tourism academia. Journal of Hospitality, Leisure, Sport \& Tourism Education, 10(1), 23-36. doi: 10.3794/johlste.101.265

Steinem, G. (2015). My Life on the Road. New York: Random House.

Steinpreis, R. E., Anders, K., \& Ritzke, D. (1999). The impact of gender on the review of the curricula vitae of job applicants and tenure candidates: a national empirical study. Sex Roles 41(7/8), 509-528. doi: 10.1023/A:101883920

Strid, S., \& Husu, L. (Eds.). (2013). GEXcel Work in Progress Report Volume XVII. Proceedings from GEXcel Themes 11-12 Visiting Scholars: Gender Paradoxes in Changing Academic and Scientific Organization(s) (Vol. XVII).

Swain, M. B. (2016). Embodying Cosmopolitan Paradigms in Tourism Research. In A. M. Munar \& T. Jamal (Eds.), Tourism Research Paradigms: Critical and Emergent Knowledges (pp. 87-111). Bingley: Emerald. doi:10.1108/S1571-504320150000022012

Toffoletti, K., \& Starr, K. (2016). Women Academics and Work-Life Balance: Gendered Discourses of Work and Care. Gender, Work and Organization, 23(5), 489-504. doi: 10.1111 gwao.12133

UNESCO (2012). World of Gender Equality in Education of Gender Equality in Education. United Nations Educational, Scientific and Cultural Organization. Retrieved 4 September, 2016, from http://www.uis.unesco.org/Education/Documents/unesco-world-atlas-gendereducation-2012.pdf

Van den Brink, M., \& Benschop, Y. (2012). Gender practices in the construction of academic excellence: Sheep with five legs. Organization, 19(4), 507-524. doi: $10.1177 / 1350508411414293$

Veijola, S., \& Jokinen, E. (2008). Towards a hostessing society? Mobile arrangements of gender and labour. NORA-Nordic Journal of Feminist and Gender Research, 16(3), 166-181. doi: $10.1080 / 08038740802279901$

Watson, D., \& Hjorth, J. (2015). Denmark: Women's grants lost in inequality ocean. Nature, 519(7542), 158-158. doi: 10.1038/519158d

Weiss, H. (2015). 6 Reasons People Believe Stereotypes About Feminists (Even Though They're Not True). Retrieved 15 May, 2015, from http://www.bustle.com/articles/132468-6reasons-people-believe-stereotypes-about-feminists-even-though-theyre-not-true .

Wood, W., \& Eagly, A. H. (2012). 2 Biosocial Construction of Sex Differences and Similarities in Behaviour. Advances in Experimental Social Psychology, 46(1), 55-123. doi: 10.1016/B978-012-394281-4.00002-7

Roberts, S. G., \& Verhoef, T. (2016). Double-blind reviewing at EvoLang 11 reveals gender bias. Journal of Language Evolution, 1(2), 163-167. 
Ana María Munar is Associate Professor at Copenhagen Business School, Denmark. With research interests in digital technologies, epistemology, higher education, and gender, her latest publications focus on postdisciplinarity, social media and gender in academia. Over the years, Ana has served on several national and international boards and networks. Nowadays, she holds positions at the Diversity and Inclusion Council at Copenhagen Business School, the Critical Tourism Studies Network, Women Academics in Tourism and several tourism journals. She is engaged in curriculum and education development, and coordinates the tourism and hospitality concentration at the Bachelor of Service Management and Business Administration. Ana has delivered numerous conference presentations and keynote addresses in her research areas.

\footnotetext{
${ }^{\mathrm{i}}$ This study follows the different categories that the literature presents as perspectives in feminist theorizing. For an extensive analysis of the relationship between feminist theorizing, feminist epistemologies and philosophy of science see Harding (1986), Anderson (2015) and Grasswick $(2011,2013)$

ii The Tourism Research Information Network (TRINET) is an electronic bulletin board (listserv) connecting the international tourism research and education community. TRINET is the largest listserv of tourism researchers which had over 2300 members in 2016
} 